УДК 691:66-96

Д-р техн. наук Л.Й. Дворкін, канд. техн. наук А.В. Мироненко, acn. Ю.О. Степасюк (НУВГП)

L.I. Dworkin, A.V. Mironenko, Y.O. Stepasyuk

\title{
СПОСОБИ ПІДВИЩЕННЯ МІЦНОСТІ НИЗЬКОКЛІНКЕРНОГО ШЛАКОПОРТЛАНДЦЕМЕНТУ
}

\section{WAYS TO IMPROVE THE STRENGTH OF LOW-CLINKER SLAG PORTLAND CEMENT}

\begin{abstract}
Основною тенденцією сучасного розвитку будівельної промисловості та будівництва $\epsilon$ їх перехід на економні енергоресурсозберігаючі технології виробництва будівельних матеріалів. Значна частина потреб $\mathrm{y}$ сировинних матеріалах може задовольнятися за рахунок широкого використання вторинних ресурсів і відходів промисловості.

Одним із найбільш затребуваних матеріалів у сучасному будівництві $\epsilon$
\end{abstract}

портландцемент. Виробництво цементного клінкеру, як напівфабрикату для виготовлення портландцементу, вимагає високих затрат палива i енергії, що призводить до значного збільшення собівартості цементу, тому актуальним $\epsilon$ вирішення проблеми його раціонального використання.

Зменшення витрати клінкеру досягається використанням змішаних та композиційних цементів. 3 них найбільш 
широко використовують шлакопортландцемент (ШПЦ).

В останній редакції стандарту України ДСТУ Б В.2.7-46:2010 так само, як i в європейських нормах EN 197-1, передбачений шлакопортландцемент "ШПЦ III/B" iз вмістом портландцементного клінкеру в межах 5-19\%. Економічна доцільність використання такого в'яжучого також не викликає сумнівів. Для отримання 1 кВт.год електроенергії на електростанціях України затрачається від $0,3 \ldots 0,37$ кг умовного палива, енергозатрати на отримання клінкеру становлять $120 \ldots 140$ кг ум.п/т для заводів сухого способу та до 240 кг для заводів мокрого способу [4]. При економії $50 \%$ клінкеру зменшення енергозатрат на його отримання складе $60 \ldots 120$ кг ум.п./т.

Відомо, що для підвищення активності ШПЦ, особливо 3 максимальним вмістом шлаку i, відповідно, мінімальним - клінкеру, велике значення має встановлення оптимального вмісту сульфатного компоненту, тонкості помелу складових цементу і вибір відповідного модифікатора. Позитивний ефект досягається при введенні в процесі помелу шлакових цементів добавок пластифікаторів та прискорювачів твердіння.

Метою даної роботи було вивчення комплексного впливу на міцність малоклінкерного шлакопортландцементу вмісту клінкеру, сульфатного активізатора, а також інтенсифікатора твердіння, питомої поверхні і суперпластифікатора, а також, дослідження впливу виду та кількості прискорювача твердіння на міцнісні характеристики в'яжучого.

В дослідженнях використовували гранульований доменний шлак Криворізького металургійного комбінату. Як цементний клінкер (Кл) використовували клінкер Здолбунівського заводу "ПАТ Волинь-Цемент". Як сульфатний компонент ШПЦ застосовували фосфогіпс-дигідрат (ФГ) Рівненського ПАТ "Азот". Хімічний склад матеріалів наведений в табл. 1.

Таблиця 1

Хімічний склад матеріалів

\begin{tabular}{|c|c|c|c|c|c|c|c|c|}
\hline \multirow{2}{*}{ Матеріал } & \multicolumn{8}{|c|}{ Вміст оксидів, мас. \% } \\
\cline { 2 - 10 } & $\mathrm{SiO}_{2}$ & $\mathrm{Al}_{2} \mathrm{O}_{3}$ & $\mathrm{Fe}_{2} \mathrm{O}_{3}$ & $\mathrm{CaO}$ & $\mathrm{MgO}$ & $\mathrm{SO}_{3}$ & $\mathrm{MnO}$ & $\mathrm{P}_{2} \mathrm{O}_{5}$ \\
\hline Шлак & 39,52 & 6,49 & 0,12 & 47,13 & 3,10 & 1,74 & 1,15 & - \\
\hline Фосфогіпс & - & 0,36 & 0,15 & 38,4 & 0,003 & 59,7 & - & 0,67 \\
\hline Клінкер & 22,47 & 5,26 & 4,07 & 66,18 & 0,64 & 0,46 & 0,29 & - \\
\hline
\end{tabular}

За модулем основності шлак $\epsilon$ основним (модуль основності $\mathrm{M}_{0}=1,1$ ) 3 коефіцієнтом якості К=1,44.

Середній вміст мінералів у клінкері складає, мас. \%: $\mathrm{C}_{3} \mathrm{~S}-57,09 ; \mathrm{C}_{2} \mathrm{~S}-21,22$; $\mathrm{C}_{3} \mathrm{~A}-6,86, \mathrm{C}_{4} \mathrm{AF}-12,20$.

Як пластифікуючу добавку було використано суперпластифікатор СП-1(С-3) Новомосковського підприємства "Полипласт", а також гіперпластифікатор на полікарбоксилатній основі - Sika VK 225.
Як добавки - регулятори твердіння в наших дослідженнях використовувалися такі прискорювачі: солі хлоридів кальцію та заліза, сульфатів натрію та заліза, а також фториду кальцію та кремній фториду натрію.

Основні дослідження були виконані із застосуванням математичного планування експерименту. Для цього був реалізований трирівневий п'ятифакторний план На-5[3], умови планування якого наведені в табл. 2. 
Умови планування експерименту

\begin{tabular}{|c|c|c|c|c|c|c|}
\hline \multirow[t]{2}{*}{ № } & \multicolumn{2}{|l|}{ Фактори } & \multicolumn{3}{|c|}{ Рівні варіювання } & \multirow{2}{*}{$\begin{array}{c}\text { Інтервал } \\
\text { варіювання }\end{array}$} \\
\hline & Натуральні & Кодовані & -1 & 0 & +1 & \\
\hline 1 & Вміст клінкеру,\% & $\mathrm{X}_{1}$ & 5 & 12 & 19 & 7 \\
\hline 2 & $\begin{array}{l}\text { Вміст фосфогіпсу в перерахунку } \\
\text { на } \mathrm{SO}_{3}, \%\end{array}$ & $\mathrm{X}_{2}$ & 3,12 & 4,67 & 6,23 & 1,55 \\
\hline 3 & Питома поверхня в'яжучого, м²/кг $^{2}$ & $\mathrm{X}_{3}$ & 300 & 400 & 500 & 100 \\
\hline 4 & $\begin{array}{l}\text { Вміст інтенсифікатора твердіння } \\
\left(\mathrm{CaF}_{2}\right), \%\end{array}$ & $\mathrm{X}_{4}$ & 0 & 1 & 2 & 1 \\
\hline 5 & $\begin{array}{l}\text { Вміст суперпластифікатора С-3, } \\
\%\end{array}$ & $\mathrm{X}_{5}$ & 0 & 0,5 & 1 & 0,5 \\
\hline
\end{tabular}

Після проведення обробки і статистичного аналізу експериментальних даних отримані математичні моделі міцності на згин та стиск стандартних розчинів на основі досліджуваних в'яжучих у вигляді поліноміальних рівнянь регресії, які наведені в табл. 3.

Таблиця 3

Експериментально-статистичні моделі міцності розчинів на малоклінкерному шлакопортландцементі

\begin{tabular}{|c|c|}
\hline Вихідні параметри & Статистичні моделі \\
\hline $\begin{array}{c}\text { Водоцементне } \\
\text { відношення }\end{array}$ & $\mathrm{B} / Ц=0,36+0,01 \mathrm{X}_{3}+0,01 \mathrm{X}_{4}-0,03 \mathrm{X}_{5}-0,01 \mathrm{X}_{2}^{2}+0,02 \mathrm{X}_{3}^{2}-0,02 \mathrm{X}_{4}^{2}+0,01 \mathrm{X}_{1} \mathrm{X}_{2}$ \\
\hline Міцність на стиск & $\mathrm{R}_{\mathrm{cr}}^{28}=32,19+5,73 \mathrm{X}_{1}-0,7 \mathrm{X}_{2}+1,49 \mathrm{X}_{3}+0,22 \mathrm{X}_{4}+1,19 \mathrm{X}_{5}-3,32 \mathrm{X}_{1}{ }^{2}-2,42 \mathrm{X}_{2}^{2}-$ \\
у віці 28 діб & $-3,22 \mathrm{X}_{3}^{2}-4,17 \mathrm{X}_{4}^{2}+1,33 \mathrm{X}_{5}^{2}-0,65 \mathrm{X}_{1} \mathrm{X}_{2}-1,53 \mathrm{X}_{1} \mathrm{X}_{3}-2,69 \mathrm{X}_{1} \mathrm{X}_{4}-$ \\
& $-0,55 \mathrm{X}_{1} \mathrm{X}_{5}+1,28 \mathrm{X}_{2} \mathrm{X}_{3}+0,4 \mathrm{X}_{2} \mathrm{X}_{4}-3,65 \mathrm{X}_{2} \mathrm{X}_{5}-0,86 \mathrm{X}_{3} \mathrm{X}_{4}+0,2 \mathrm{X}_{3} \mathrm{X}_{5}+2,91 \mathrm{X}_{4} \mathrm{X}_{5}$ \\
\hline
\end{tabular}

Графічні залежності, які ілюструють вплив технологічних факторів на водоцементне відношення та міцність малоклінкерного ШПЦ на стиск у віці 28 діб, наведені на рис. 1, 2.

Аналізуючи графіки, наведені на рис. 1, приходимо до висновку, що збільшення вмісту клінкеру суттєво не впливає на водоцементне відношення. Суттєвий вплив на нього має величина питомої поверхні в'яжучого. При збільшенні питомої поверхні до величини $400 \mathrm{~m}^{2} / к г$ водопотреба в'яжучого знижується, що повязано із збільшенням пластичності розчинів при збільшенні дисперсності частинок в'яжучого, проте надмірне іiі збільшення призводить до різкого зростання В/Ц. Також до деякого зростання водопотреби призводить збільшення вмісту активізатора твердіння фториду кальцію. Вплив даних двох факторів має екстремальний характер. Збільшення вмісту фосфогіпсу до величини $7,5 \% \quad\left(4,63 \%\right.$ у перерахунку на $\left.\mathrm{SO}_{3}\right)$ у загальній масі в'яжучого призводить до незначного збільшення В/Ц, це збільшення пов'язане 3 утворенням підвищеної кількості етрингіту в результаті взаємодії алюмінатної складової цементного клінкеру 3 сульфатною складовою фосфогіпсу. Проте коли алюмінатна складова повністю витрачається на його 
утворення, то подальше збільшення вмісту фосфогіпсу веде до незначного зниження В/Ц. За таких умов для зниження кількості води, необхідної для отримання розчину 3 розпливом конусу рівним 106-115 мм доцільним є введення суперпластифікатора C-3, що дозволяє зменшити водопотребу від $\mathrm{B} / Ц=0,39$ до $\mathrm{B} / Ц=0,33$, або гіперпластифікатора Sika VK 225, що дозволяє зменшити водопотребу до В/Ц=0,25 i, відповідно, збільшити міцність зразків. Вплив суперпластифікатора на В/Ц найбільший і він має практично лінійний характер (рис. 1).
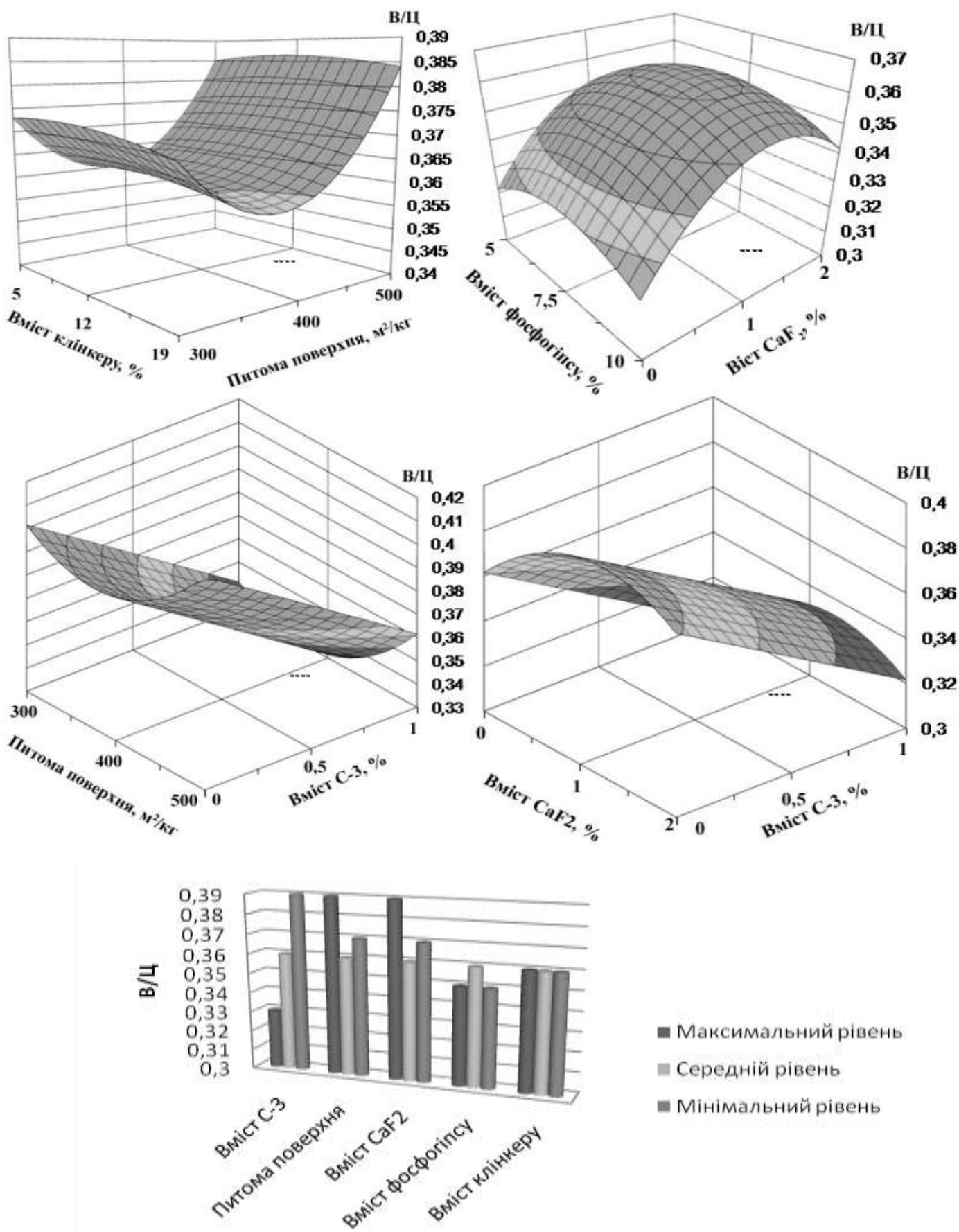

- Максимальнийрівень

- Середній рівень

= Мінімальний рівень

Рис. 1. Вплив технологічних факторів на водоцементне відношення розчинів на основі малоклінкерного шлакопортландцементу 

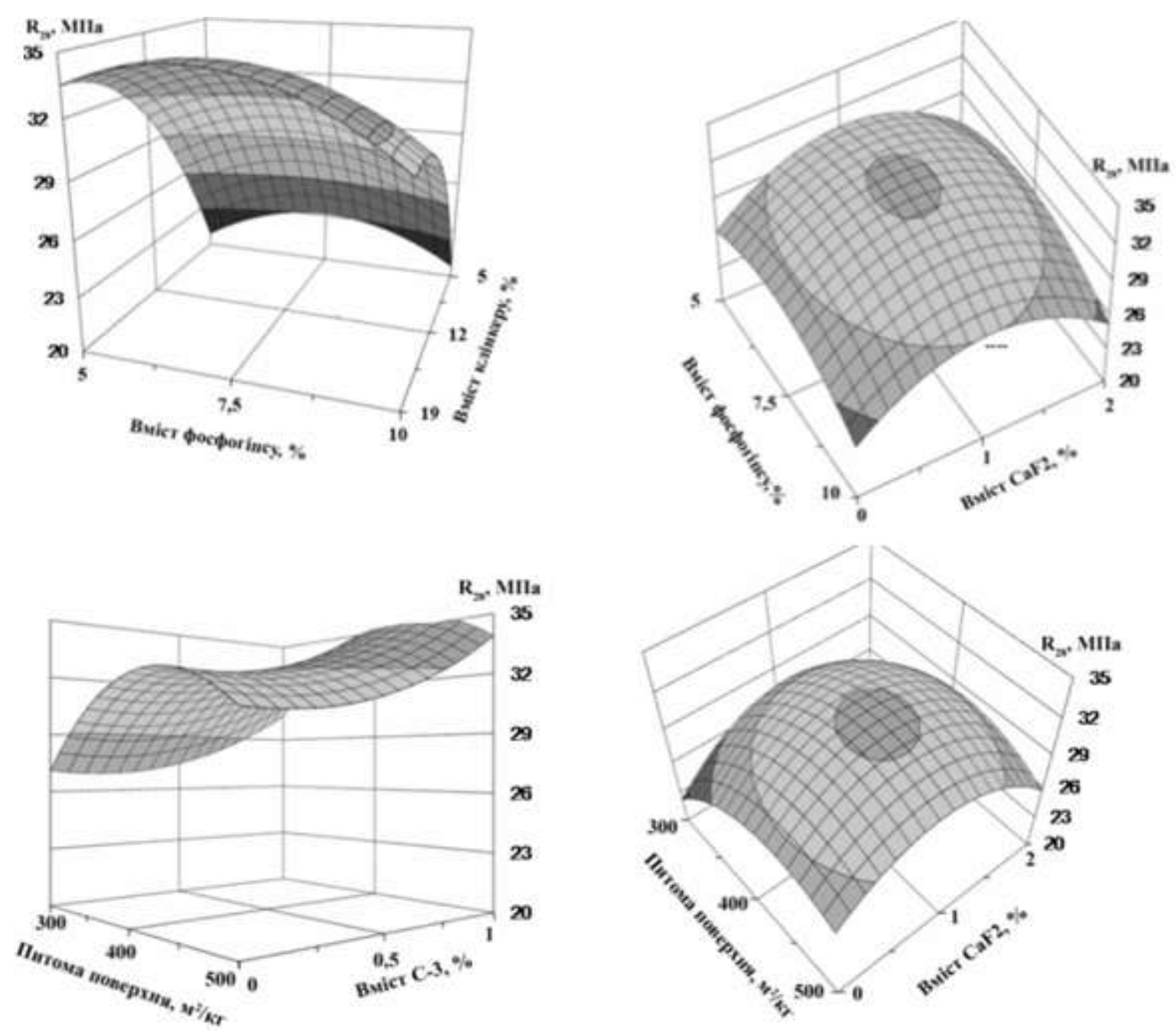

Рис. 2. Вплив технологічних факторів на міцність зразків у віці 28 діб, виготовлених на основі малоклінкерного шлакопортландцементу

Аналізуючи наведені на рис. 2 графіки, приходимо до висновку, що найбільший вплив на активність малоклінкерного шлакопортландцементу має вміст клінкеру у в'яжучому, при збільшенні якого міцність ШПЦ збільшується на 10-15\%. Також позитивно на міцність впливає збільшення вмісту добавки фториду кальцію, оптимальний вміст якої складає 1\% від маси в'яжучого. Подальше збільшення його вмісту призводить до спаду міцності зразків, що пояснюється збільшенням водопотреби суміші. Також зростанню міцності сприяє збільшення питомої поверхні в'яжучого, але це призводить до зростаня В/Ц суміші, тому для підвищення активності ШПЦ доцільне введення суперпластифікатора, що дозволяє зменшити його водопотребу. Оптимальна витрата суперпластифікатора у складі в'яжучого становить $1 \%$. Збільшення вмісту фосфогіпсу до 7,5\% $\quad(4,63 \%$ у перерахунку на $\left.\mathrm{SO}_{3}\right)$ призводить до збільшення активності в'яжучого, але подальше його зростання негативно впливає на міцність.

Також в даній роботі було виконано ряд дослідів по встановленню впливу прискорювачів твердіння на міцнісні характеристики в'яжучого 3 різною величиною питомої поверхні: 300-320 м²/кг та 400-450 м²/кг. При цьому 
використовувалось в'яжуче такого складу: клінкер - $12 \%$, доменний гранульований шлак - $88 \%$, фосфогіпс - 7,5 \% (4,63 в перерахунку на $\left.\mathrm{SO}_{3}\right), \quad$ вміст суперпластифікатора С-3 - 1 \%. Результати досліджень наведені в табл. 4.

Отримані результати вказують на те, що на міцність малоклінкерного шлакопортландцементу найбільш суттєво впливає величина питомої поверхні, при іiі збільшенні від 300-320 м²/кг до 400-450 $\mathrm{m}^{2} /$ кг міцність збільшується майже удвічі. Проте збільшити міцність вяжучого 3 питомою поверхнею 300-320 м²/кг можна, викоритовуючи прискорювачі твердіння.
Наші дослідження показали, що найбільш ефективним прискорювачем твердіння, при такій величині питомої поверхні, для малоклікерного шлакопортландцементу $\epsilon$ кремнійфтористий натрій $\left(\mathrm{Na}_{2} \mathrm{SiF}_{6}\right)$. Міцність в'яжучого при збільшенні його вмісту до величини $2 \%$ зростає більше ніж в 1,5 рази, але подальше збільшення вмісту $\mathrm{Na}_{2} \mathrm{SiF}_{6}$ призводить до зниження міцності, що повязано зі збільшенням В/Ц. Із збільшенням питомої поверхні вплив прискорювачів твердіння на міцнісні характеристики в'яжучого стає незначним.

Таблиця 4

Вплив добавок прискорювачів твердіння на міцність малоклінкерного шлакопортландцементу

\begin{tabular}{|c|c|c|c|c|c|c|c|c|c|c|c|c|}
\hline \multirow{3}{*}{ № } & \multirow{2}{*}{\multicolumn{2}{|c|}{ Добавка }} & \multicolumn{5}{|c|}{$\begin{array}{c}\text { Питома поверхня } \\
300 \mathrm{~m}^{2} / \mathrm{\kappa} \Gamma\end{array}$} & \multicolumn{5}{|c|}{ Питома поверхня 400 м²/кг } \\
\hline & & & \multirow{2}{*}{$\frac{\mathrm{B}}{Ц}$} & \multicolumn{2}{|c|}{$\begin{array}{c}\text { Міцність } \\
\text { при згині, } \\
\text { МПа }\end{array}$} & \multicolumn{2}{|c|}{$\begin{array}{l}\text { Міцність при } \\
\text { стиску, Мпа }\end{array}$} & \multirow{2}{*}{$\frac{\mathrm{B}}{Ц}$} & \multicolumn{2}{|c|}{$\begin{array}{c}\text { Міцність } \\
\text { при згині, } \\
\text { МПа }\end{array}$} & \multicolumn{2}{|c|}{$\begin{array}{c}\text { Міцність } \\
\text { при стиску, } \\
\text { Мпа }\end{array}$} \\
\hline & Вид & $\begin{array}{l}\text { Вміст, } \\
\text { мас. } \%\end{array}$ & & 7 діб & $\begin{array}{c}28 \\
\text { діб }\end{array}$ & 7 діб & 28 діб & & 7 діб & $\begin{array}{c}28 \\
\text { діб }\end{array}$ & 7 діб & $\begin{array}{c}28 \\
\text { діб }\end{array}$ \\
\hline 1 & $\begin{array}{c}\text { Без добавок } \\
\text { (конт- } \\
\text { рольний) }\end{array}$ & - & 0,33 & 5,1 & 0,33 & 16,3 & 25,4 & 0,32 & 7,4 & 32,8 & 10,8 & 48,3 \\
\hline 2 & $\mathrm{Na}_{2} \mathrm{SiF}_{6}$ & 1,0 & 0,35 & 7,1 & 9,5 & 28,4 & 33,2 & 0,34 & 6,5 & 9,0 & 26,0 & 44,1 \\
\hline 3 & $\mathrm{Na}_{2} \mathrm{SiF}_{6}$ & 2,0 & 0,38 & 6,8 & 9,5 & 29,6 & 44,3 & 0,37 & 7,4 & 9,0 & 21 & 45,6 \\
\hline 4 & $\mathrm{Na}_{2} \mathrm{SO}_{4}$ & 1,0 & 0,36 & 5,6 & 9,6 & 20,2 & 40,8 & 0,34 & 8,6 & 10,8 & 26,6 & 48,3 \\
\hline 5 & $\mathrm{Na}_{2} \mathrm{SO}_{4}$ & 2,0 & 0,36 & 5,0 & 8,4 & 16,2 & 36,0 & 0,36 & 7,4 & 11,1 & 26,2 & 47,5 \\
\hline 6 & $\mathrm{Fe}_{2}\left(\mathrm{SO}_{4}\right)_{3}$ & 1,0 & 0,34 & 5,4 & 8,9 & 17,6 & 40,5 & 0,34 & 7,7 & 10,1 & 27,6 & 46,7 \\
\hline 7 & $\mathrm{Fe}_{2}\left(\mathrm{SO}_{4}\right)_{3}$ & 2,0 & 0,36 & 5,2 & 8,8 & 13,4 & 21,8 & 0,36 & 6,5 & 11,2 & 24,2 & 42,1 \\
\hline 8 & $\mathrm{CaCl}_{2}$ & 1,0 & 0,31 & 4,0 & 8,2 & 15 & 23,6 & 0,35 & 5,1 & 9,9 & 16,5 & 41,8 \\
\hline 9 & $\mathrm{CaCl}_{2}$ & 2,0 & 0,32 & 4,7 & 8,6 & 22 & 23,4 & 0,36 & 5,1 & 10,0 & 26,0 & 41,3 \\
\hline 10 & $\mathrm{FeCl}_{3}$ & 1,0 & 0,34 & 4,9 & 8,6 & 19 & 23,8 & 0,34 & 9,2 & 10,2 & 31,4 & 45,1 \\
\hline 11 & $\mathrm{FeCl}_{3}$ & 2,0 & 0,35 & 4,7 & 8,9 & 19,2 & 19,7 & 0,36 & 8,1 & 10,7 & 29,2 & 47,4 \\
\hline
\end{tabular}

Висновок. Дослідження показали можливість отримання малоклінкерного шлакопортландцементу активністю більше 50 МПа із застосуванням двокомпонентних добавок-модифікаторів: суперпластифікатора C-3 та активізатора твердіння фториду кальцію $\left(\mathrm{CaF}_{2}\right)$. При цьому в'яжуче має такий склад: вміст клінкеру - $12 \%$, вміст доменного гранульованого шлаку - $88 \%$, вміст фосфогіпсу - 7,5 \% (в перерахунку на $\mathrm{SO}_{3}-4,63$ \%). Питома поверхня в'яжучого складає $400-450 \mathrm{~m}^{2} / \kappa г$, витрата добавки 
суперпластифікатора C-3 - 1\%, та добавки ативізатора твердіння фториду кальцію $\left(\mathrm{CaF}_{2}\right)-1 \%$ від загальної маси в'яжучого. Було встановлено можливість отримання малоклінкерного шлакопортландцементу активністю більше $40 \mathrm{MПа} \mathrm{із} \mathrm{застосуван-}$ ням добавок - прискорювачів твердіння, найбільш ефективним 3 яких $\epsilon$ кремній фтористий натрій $\left(\mathrm{Na}_{2} \mathrm{SiF}_{6}\right)$. Питома поверхня в'яжучого при цьому складає $300-320 \mathrm{~m}^{2} / \mathrm{K} \Gamma$.

\section{Сиисок літератури}

1. Рунова, Р.Ф. В'яжучі речовини [Текст]: підручник / Р.Ф. Рунова, Л.Й. Дворкін, О.Л. Дворкін, Ю.Л. Носовський. - К.: Основа, 2012.

2. Дворкін, Л.Й. Використання техногенних продуктів у будівництві [Текст] / Л.Й. Дворкін, О.Л. Дворкін, К.К. Пушкарьова, М.О. Кочевих, М.А. Мохорт, М.П. Безсмертний. - Рівне: НУВГП, 2009.

3. Дворкін, Л.Й. Розв'язування будівельно-технологічних задач методами математичного планування експерименту [Текст] / Л.Й. Дворкін, О.Л. Дворкін, В.В. Житковський. - Рівне: НУВГП, 2011.

4. Дворкин, Л.И. Снижение расхода цемента и топлива в производстве сборного железобетона. - К.: Вища школа, 1985.

Ключові слова: енергозбереження, шлакопортландцемент, клінкер, фосфогіпс, добавки-модифікатори.

\section{Анотаціï}

В статті наведені результати досліджень шлакопортландцементу зі вмістом клінкеру 5-19 \%. Визначені оптимальні склади і параметри виробництва та запропоновані комплексні добавки - модифікатори для отримання шлакопортландцементу з активністю до 50 МПа.

В статье приведены результаты исследований шлакопортландцемента с содержанием клинкера 5-19 \%. Определены оптимальные составы и параметры производства, предложены комплексные добавки-модификаторы для получения шлакопортландцемента с активностью до 50 МПа.

In the article are presented the results of Slag Portlandcement studies with clinker content 5-19\%. The optimal compositions and technological parameters and additives - modifiers for low clinker Slag Portlandcement with activity up to $50 \mathrm{MPa}$ are proposed. 